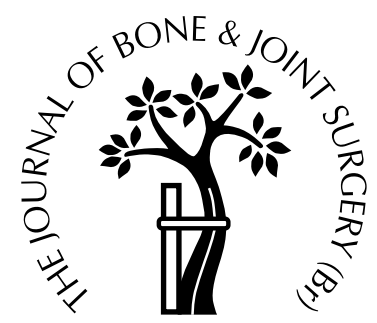

\title{
Development of the ball-and-socket ankle as assessed by radiography and arthrography
}

\author{
A LONG-TERM FOLLOW-UP REPORT \\ Y. Takakura, Y. Tanaka, T. Kumai, K. Sugimoto \\ From Nara Medical University, Nara, Japan
}

W

e studied the development of ball-and-socket deformity of the ankle by arthrography and radiography in 14 ankles of ten patients with congenital longitudinal deficiency of the fibula accompanied by various anomalies. The mean follow-up was for 18 years 10 months.

In three ankles in infants less than one year old the lateral and medial sides of the ankle were already slightly round. In another seven ankles the ball-and-socket appearance developed before the age of five years. This was thought to be due to osseous coalition which limits eversion and inversion. In another four ankles in children who were over the age of one year at the initial examination, the deformity was demonstrated by arthrography and radiography at their first examination.

Ball-and-socket deformity accompanied by tarsal coalition is an acquired deformity secondary to limitation of movement of the subtalar and midtarsal joints. It has completely developed by about five years of age.

J Bone Joint Surg [Br] 1999;81-B:1001-4.

Received 9 March 1999; Accepted after revision 13 April 1999

Congenital deformities of the foot such as club foot, ${ }^{1,2}$ flat foot $^{3-5}$ or vertical talus ${ }^{6,7}$ should be corrected when the plasticity of the tarsal bones is high. The ball-and-socket deformity of the ankle is a rare condition in which the ankle mortise assumes a spherical shape. It is accompanied by such anomalies as shortening of the limb, aplasia or hypoplasia of the fibula, tarsal coalition and absent or fused rays. There are currently two theories as to the aetiology. It may itself represent a congenital abnormality or it may be

Y. Takakura, MD, PhD, Associate Professor

Y. Tanaka, MD, PhD, Clinical Fellow

T. Kumai, MD, PhD, Clinical Fellow

K. Sugimoto, MD, PhD, Clinical Fellow

Department of Orthopaedic Surgery, Nara Medical University, Nara

634-8522, Kashihara, Japan.

Correspondence should be sent to Dr Y. Takakura.

(C)1999 British Editorial Society of Bone and Joint Surgery

0301-620X/99/69993\$2.00

VOL. 81-B, No. 6, NOVEMBER 1999 caused by secondary adaptation. ${ }^{8-12}$ In 1986 we suggested that the deformity was not congenital, but secondary to coalition. ${ }^{12}$ We have now been able to carry out a longer follow-up on the original patients and also to study others. In this report, we discuss the shape of the ankle and the age of development of the deformity in more detail.

\section{Patients and Methods}

There were seven males and three females with ball-andsocket deformity of the ankle; in four the involvement was bilateral (Table I). Their ages ranged from 16 days to five years and two months when first seen and their mean age at the latest review was 19.8 years ( 7 to 28 ).

Congenital longitudinal deficiency of the fibula is accompanied by many deformities including the ball-andsocket ankle. All the patients with unilateral involvement had shortening of the affected lower limb and all with bilateral abnormalities were below average height because of shortening on both sides. Tarsal coalition and absent or fused rays were seen in all patients. Coalition of the talocalcaneal, the calcaneocuboid or talonavicular joints was also seen in all patients. In 12 cases there was hypoplasia and aplasia of the fibula, in 12 pes planovalgus and in two congenital club foot (Table I).

We performed arthrography in patients less than five years of age and plain radiography in those over five years (Figs 1 and 2). At arthrography, we injected $0.3 \mathrm{ml}$ of $30 \%$ urografin into infants less than two years of age, and $0.5 \mathrm{ml}$ of $60 \%$ urografin and $0.5 \mathrm{ml}$ of air into older children. The anteroposterior radiograph of the ankle was taken in $10^{\circ}$ of internal rotation.

The ankles were classified into four groups: normal; stage I, a slightly rounded corner; stage II, both medial and lateral corners rounded; and stage III, a completely spherical ankle (Figs 1 and 2). Patients were examined regularly to determine when the ball-and-socket appearance began and by what age its development was complete. They were also seen at maturity.

\section{$\underline{\text { Results }}$}

The mean follow-up between the first radiological examination and the latest review was 18 years 10 months ( 7 


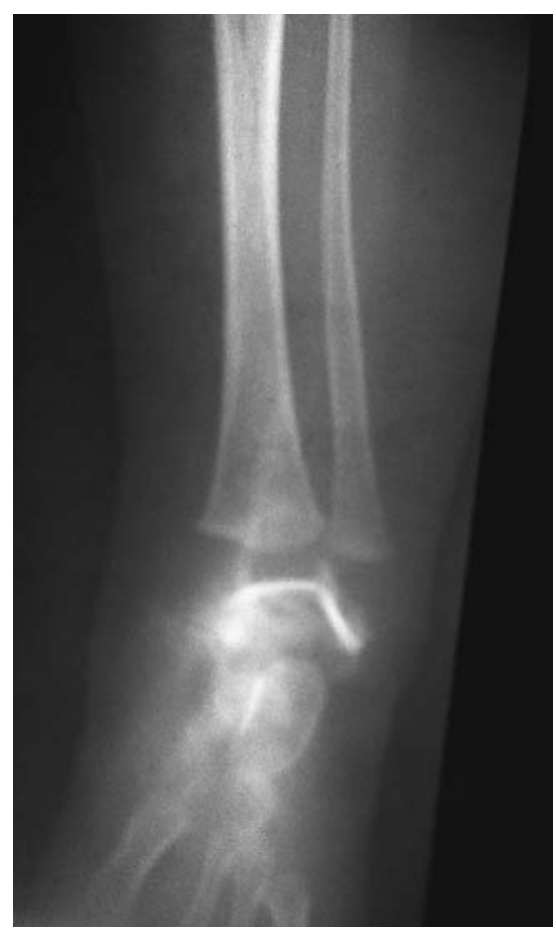

Fig. 1a

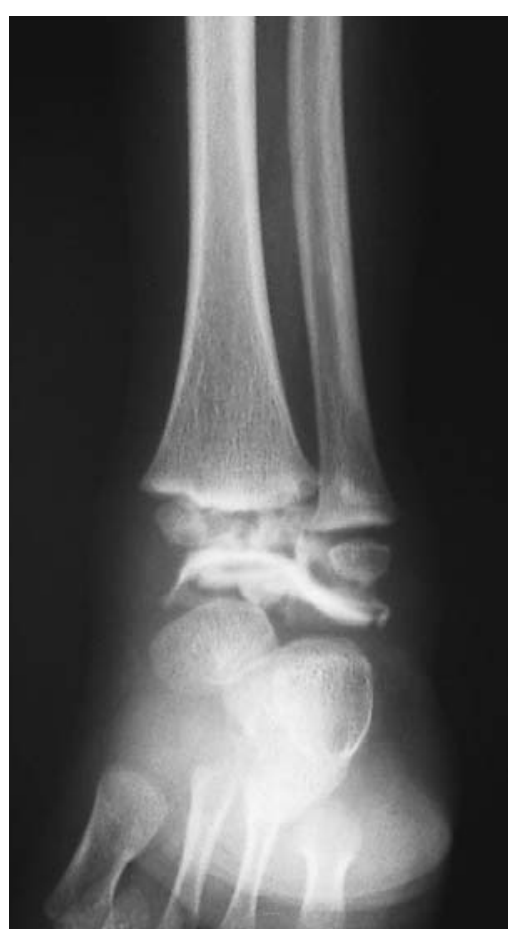

Fig. 1b

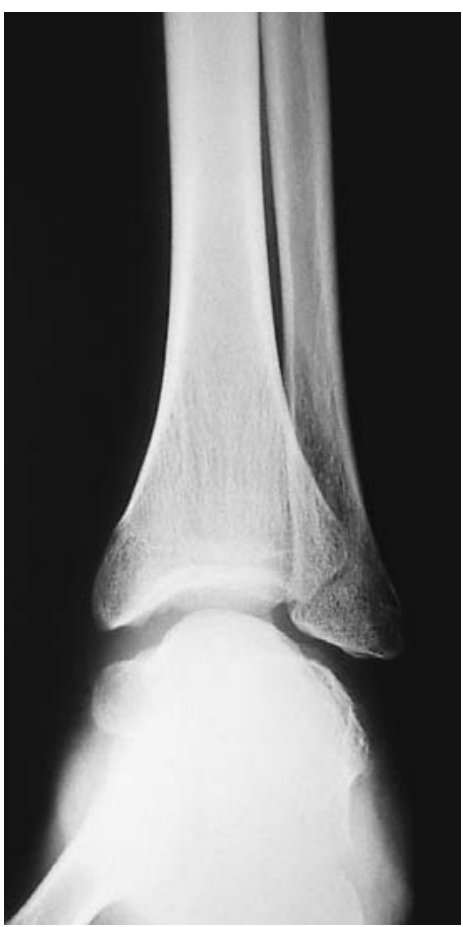

Fig. 1c

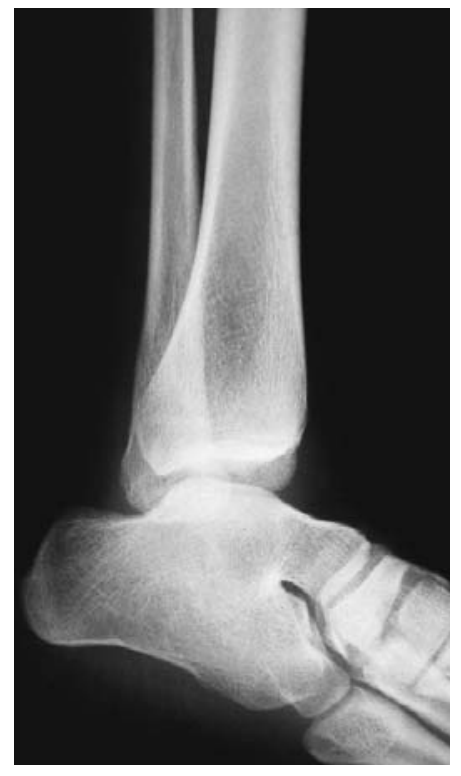

Fig. 1d

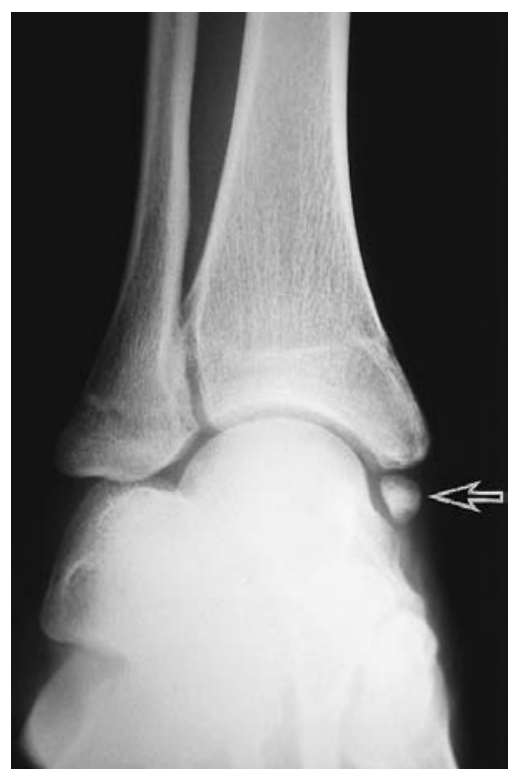

Fig. 1e

Case 2. Figures 1a, 1b - Arthrographs of the left ankle showing a) a normal ankle at six months of age including lateral and medial facets on the anteroposterior view and b) at four years of age with rounded lateral and medial corners. Figures 1c, $1 \mathrm{~d}, 1 \mathrm{e}-$ At 25 years of age plain radiographs show c) a ball-and-socket joint (stage III), d) the coalition of the talocalcaneal, talonavicular and calcaneocuboid bones on the lateral view and e) a completely spherical ball-and-socket ankle (stage III) and an os subtibiale beneath the medial malleolus (arrow).

years 6 months to 25 years 5 months) (Table I). Tarsal coalition was seen in all patients: talocalcaneal in two feet, talocalcaneal and calcaneocuboid in three, talocalcaneal and talonavicular in two, talonavicular and calcaneocuboid in three, talocalcaneal, talonavicular and calcaneocuboid in three (Fig. 1d) and gross coalition of all the tarsal bones in one. In six ankles of five patients the os subtibiale was observed beneath the medial malleolus (Fig. 1e). Three of these patients complained of mild local discomfort. No ankle developed gross degenerative changes.
We performed arthrography on ten joints of seven infants of less than one year old. Seven ankles were classified as normal, two as stage I and one as stage II. They all progressed to stage III by a mean age of 5 years 1 month ( 3 years 9 months to 6 years 2 months) (Figs 1 and 2).

Of three children (four ankles) over the age of one year, one who was classified as stage II developed to stage III by the age of 4 years 8 months. Two children who had their first examination at the age of five and seven years already had stage-III deformity, suggesting that the deformity is complete by five years of age. 
Table I. Details of the ten patients with ball-and-socket ankle

\begin{tabular}{|c|c|c|c|c|c|c|c|c|c|c|c|c|c|}
\hline \multirow[b]{2}{*}{ Case } & \multirow{2}{*}{$\begin{array}{l}\text { Age } \\
(\mathbf{y r})\end{array}$} & \multirow[b]{2}{*}{ Gender } & \multirow{2}{*}{$\begin{array}{l}\text { Involved } \\
\text { foot }\end{array}$} & \multirow{2}{*}{$\begin{array}{l}\text { First } \\
\text { exam- } \\
\text { ination }\end{array}$} & \multirow[b]{2}{*}{ Follow-up } & \multirow{2}{*}{$\begin{array}{l}\text { Tarsal } \\
\text { coalition }\end{array}$} & \multirow{2}{*}{$\begin{array}{l}\text { Fibular } \\
\text { hypoplasia } \\
\text { and aplasia }\end{array}$} & \multirow{2}{*}{$\begin{array}{l}\text { Pes } \\
\text { plano- } \\
\text { valgus }\end{array}$} & \multirow{2}{*}{$\begin{array}{l}\text { Con- } \\
\text { genital } \\
\text { club foot }\end{array}$} & \multicolumn{4}{|c|}{ Radiological changes* } \\
\hline & & & & & & & & & & Newborn & 2 to $3 \mathrm{yr}$ & 4 to $5 \mathrm{yr}$ & Over 6 yr \\
\hline 1 & 28 & $\mathrm{~F}$ & Left & $5 \mathrm{yr} 2 \mathrm{mth}$ & $23 \mathrm{yr}$ & + & + & + & - & - & - & III & III \\
\hline \multirow[t]{2}{*}{2} & 25 & M & Right & 20 days & $25 \mathrm{yr} 2 \mathrm{mth}$ & + & + & + & - & I & II & III & III \\
\hline & & & Left & & & + & + & - & + & Normal & II & III & III \\
\hline \multirow[t]{2}{*}{3} & 24 & M & Right & $1 \mathrm{mth}$ & 24 yr $5 \mathrm{mth}$ & + & + & + & - & Normal & II & III & III \\
\hline & & & Left & & & + & + & + & - & Normal & I & III & III \\
\hline 4 & 22 & M & Right & 7 days & $22 \mathrm{yr} 8 \mathrm{mth}$ & + & + & + & - & Normal & II & III & III \\
\hline 5 & 22 & $\mathrm{~F}$ & Left & $3 \mathrm{mth}$ & $22 \mathrm{yr}$ & + & + & + & - & II & III & III & III \\
\hline \multirow[t]{2}{*}{6} & 21 & M & Right & $7 \mathrm{yr}$ & $14 \mathrm{yr} 4 \mathrm{mth}$ & + & + & + & - & - & - & - & III \\
\hline & & & Left & & & + & - & + & - & - & - & - & III \\
\hline \multirow[t]{2}{*}{7} & 20 & M & Right & $1 \mathrm{mth}$ & $20 \mathrm{yr}$ & + & + & + & - & Normal & I & II & III \\
\hline & & & Left & & & + & + & + & - & I & II & III & III \\
\hline 8 & 15 & M & Left & $2 \mathrm{yr}$ & $13 \mathrm{yr} 1 \mathrm{mth}$ & + & + & + & - & - & II & III & III \\
\hline 9 & 14 & M & Right & 16 days & $14 \mathrm{yr} 9 \mathrm{mth}$ & + & + & - & + & Normal & II & III & III \\
\hline 10 & 7 & $\mathrm{~F}$ & Right & $2 \mathrm{mth}$ & 7 yr $6 \mathrm{mth}$ & + & - & + & - & Normal & $\mathrm{I}$ & III & III \\
\hline Mean & 19.8 & $\pm 6.2 \mathrm{yr}$ & & $1 \mathrm{yr} 7 \mathrm{mth}$ & 18 yr $8 \mathrm{mth}$ & & & & & & & & \\
\hline
\end{tabular}

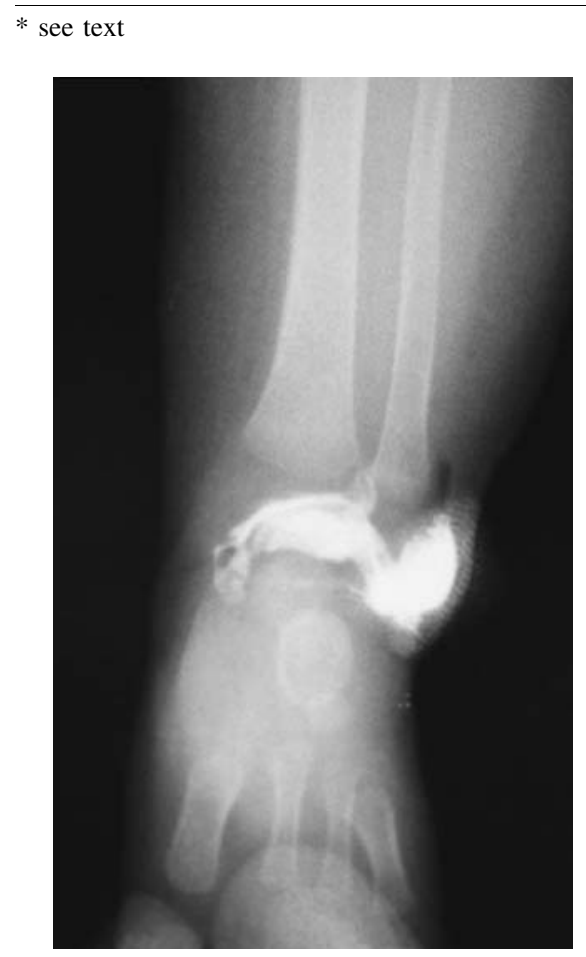

Fig. 2a

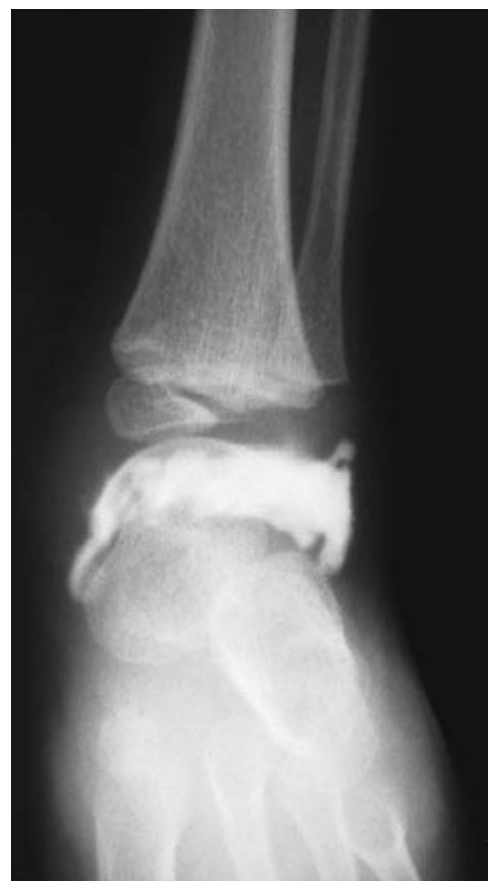

Fig. 2b

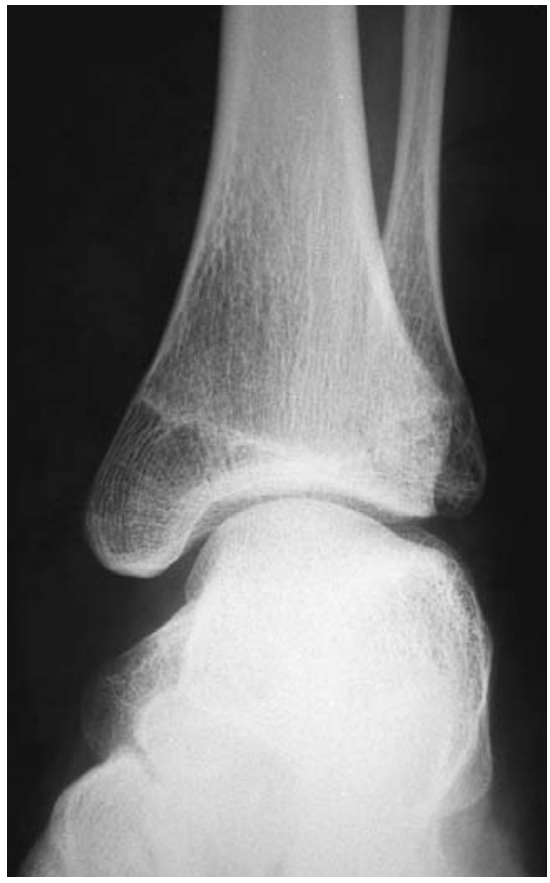

Fig. 2c

Case 7. Figures $2 \mathrm{a}, 2 \mathrm{~b}$ - Arthrographs of the left ankle at a) ten months old showing a slightly rounded medial corner on the anteroposterior view (stage I) and b) 4 years and 6 months with a clearly rounded medial corner and a slightly rounded lateral corner (stage II or III). Figure $2 \mathrm{c}-\mathrm{A}$ plain radiograph at 20 years of age shows a complete ball-and-socket joint (stage III).

\section{Discussion}

A variety of deformities caused by intrauterine and congenital factors affect the feet of newborn infants. ${ }^{3,4}$ Most mild deformities correct spontaneously. Congenital club foot, ${ }^{1,2}$ congenital flat foot $^{3-5}$ and congenital vertical talus ${ }^{6,7}$ may be resistant to treatment. These conditions are usually caused by deformity or malalignment of the tarsal bones, and they should be corrected when the plasticity of these structures remains high. The present study demonstrates the age of development of the ball-and-socket deformity of the ankle.
Since the ball-and-socket ankle was first described by Lamb $^{10}$ in 1958, its aetiology has been a subject of debate. ${ }^{8-12}$ We have been able to study ten patients for a considerable period of time. Repeated arthrography and radiography from soon after birth showed that the ankle was not congenitally spherical but developed this shape by five years of age. Loss of movement at the subtalar and midtarsal joints as a result of tarsal coalition causes abnormal inversion and eversion of the ankle. ${ }^{9,12}$ The abnormal movement produces changes in the shape of the joint medially and laterally. Three joints had already developed this shape at birth probably because of abnor- 
mal ankle movement during intrauterine development.

In six ankles $(43 \%)$ we observed the os subtibiale beneath the medial malleolus. The incidence of the presence of this accessory bone has been reported as between $0.2 \%$ and $2.1 \%$. It may be difficult to differentiate the accessory bone from a secondary ossification centre, but all the ankles with the os subtibiale were completely spherical. The high incidence of this ossicle in our study appears to be due to separation of a secondary ossification centre of the medial malleolus caused by repeated eversion of an abnormal ankle.

\section{References}

1. Attenborough CG. Early posterior soft-tissue release in severe congenital talipes equinovarus. Clin Orthop 1972;84:71-8.

2. Turco VJ. Resistant congenital club foot-one-stage posteromedial release with internal fixation: a follow-up report of a fifteen-year experience. J Bone Joint Surg [Am] 1979;61-A:805-14.

3. Giannestras NJ. Foot disorders: medical and surgical management. Second edition, Philadelphia: Lea and Febiger, 1973:120-34.

4. Bordelon RL. Flatfoot in children and young adults. In: Mann RA, Coughlin MJ, eds. Surgery of the foot and ankle. Sixth ed. Vol 1. St Louis, etc: Mosby, 1992:717-56.

5. Wenger DR, Mauldin D, Speck G, Morgan D, Lieber RL. Corrective shoes and inserts as treatment for flexible flatfoot in infants and children. J Bone Joint Surg [Am] 1989;71-A:800-10.

6. Drennan JC. Congenital vertical talus. AAOS Instr Course Lect 1996;45: 315-22.
Once the development of the spherical ankle is complete the morphology of the joint changes little. The age of complete development of the ball-and-socket deformity was slightly longer than that of normal ankles, possibly because of associated anomalies; the development of abnormal tarsal bones may be delayed compared to the normal.

No benefits of any form have been received or will be received from any commercial party related directly or indirectly to the contents of this article. No funds were received in support of this study.

7. Klein DM, Merola AA, Spero CR. Congenital vertical talus with a talocalcaneal coalition. J Bone Joint Surg [Br] 1996;78-B:326-7.

8. Fischer V, Refior HJ. Ball and socket ankle joint in tarsal synostoses. Arch Orthop Unfallchir (German) 1972;73:278-85.

9. Imhauser G. Ball-shaped ankle-joint in congenital tarsal synostoses: relation of form and function. Z Orthop Ihre Grenzgeb 1970;108: 247-58.

10. Lam D. The ball and socket ankle joint: a congenital anomaly. $J$ Bone Joint Surg [Br] 1958;40-B:240-3.

11. Pappas AM, Miller JT. Congenital ball-and-socket ankle joints and related lower-extremity malformations. J Bone Joint Surg [Am] 1982; 64-A:672-9.

12. Takakura Y, Tamai S, Masuhara K. Genesis of ball-and-socket ankle. J Bone Joint Surg [Br] 1986;68-B:834-87. 